\title{
STUDIES WITH RADIOACTIVE IODIZED FAT. I. PREPARATION OF RADIOACTIVE FAT WITH OBSERVATIONS ON THE ABSORPTION OF FAT FOLLOWING SUBCUTANEOUS AND INTRAPERITONEAL INJECTION IN DOGS ${ }^{1}$
}

\author{
By ALEXANDER M. RUTENBURG, ARNOLD M. SELIGMAN, AND JACOB FINE
}

(From the Kirstein Laboratory for Surgical Research, Beth Israel Hospital, and the Department of Surgery, Harvard Medical School, Boston)

(Received for publication March 14, 1949)

\section{INTRODUCTION}

The intravenous administration of emulsified fat in concentrations suitable for nutritional purposes is not applicable for clinical use because an emulsion stabilizer free of undesirable effects has not yet been developed. Pending the availability of a satisfactory stabilizer, the possibility of parenteral administration of fat by other routes deserves further exploration. Data reported on the absorption and distribution of fat given subcutaneously, intramuscularly and intraperitoneally to animals (1-6) are equivocal or conflicting largely because of the inadequacy of the quantitative analytical methods used. Fat labelled with a radioactive element can be traced and measured with considerable accuracy. While fat labelled with radioactive carbon $\left(\mathrm{C}^{14}\right)(7)$ or deuterium (8) is ideal, the measurement in tissue is more difficult than that of fat labelled with radioactive iodine. Although iodized fat is unnatural, its digestion, absorption and metabolic fate after oral and parenteral administration is said to simulate closely that of natural fat (9-15). Since iodine is liberated relatively slowly from iodized fat (16), it should, if radioactive, be useful to follow the absorption and immediate distribution of fat, once it enters the circulation. Accordingly, an emulsion of fat labelled with radioactive iodine was prepared with Demal $14^{2}$ in order to determine with reasonable accuracy, (1) the absorption and distribution of fat introduced subcutaneously or intraperitoneally, and (2) the distribution of radioactive fat emulsions introduced intravenously. This communication presents a method for the preparation of radioactive fat, to-

\footnotetext{
1 Aided by a grant from the Patrons of Research, Beth Israel Hospital, Boston.

2 A preparation of polyglycerol esters provided through the courtesy of Emulsol Corp., Chicago.
}

gether with data on the absorption of such fat from the subcutaneous and intraperitoneal spaces, with and without hyaluronidase. In a subsequent paper (16), observations on the distribution and fate of radioactive fat emulsions injected intravenously are presented.

\section{EXPERIMENTAL METHODS}

\section{Iodination of soya bean oil}

A modification of the method for iodination of vegetable oil with iodine monochloride (17) was used for iodination of soya bean oil with $\mathrm{I}^{121} \mathrm{Cl}$. By this method only one atom of iodine is incorporated upon halogenation of an ethylenic linkage. By using an excess of oil an average of 0.46 atoms of iodine was incorporated into each molecule of fat. ${ }^{3}$

Potassium iodide ( $3.6 \mathrm{gms}$.) was dissolved in $6.2 \mathrm{cc}$ of distilled water, to which one to two molecules of carrierfree $\mathrm{I}^{13 \mathrm{~s}}(1 \mathrm{cc}$.) and $2.4 \mathrm{gms}$. of potassium iodate were added. Concentrated hydrochloric acid $(7.2 \mathrm{cc}$.) was added slowly with vigorous shaking and stirring. The resulting heavy dark precipitate of $\mathrm{I}^{131} \mathrm{Cl}$ slowly redissolved. A small amount of iodine vapor appeared in the reaction flask during the procedure. The final solution was clear and orange colored. A highly diluted aliquot was taken for radioactivity measurement.

The $\mathrm{I}^{13 \mathrm{C}} \mathrm{Cl}$ solution was cooled to $45^{\circ} \mathrm{C}$. and added in three portions with stirring to a cold solution of $50-55$ gms. of soya bean oil in $100 \mathrm{cc}$. ether. The mixture was mechanically shaken for $60-90$ minutes at room temperature. The color of the aqueous solution was discharged during this process. The oil-ether solution was straw yellow. It was washed once with water and twice with $5 \%$ sodium sulfite in $0.1 \mathrm{~N}$ sodium hydroxide solution. It was then washed with water, dilute hydrochloric acid, and finally several times with distilled water. The combined washings contained $2 \%$ of the total radioactivity used in the iodination.

\footnotetext{
3 Pure refined soya bean oil was supplied by E. F. Drew \& Co., Inc., Boston. It contains $33.7 \%$ oleic acid, $52.0 \%$ linoleic acid, $2.3 \%$ linolenic acid and $11.2 \%$ palmitic and stearic acids. The molecular weight of this oil is about 876 and each molecule contains approximately 4.3 double bonds.
} 
The ether solution was dried with anhydrous sodium sulfate and the ether was removed by distillation under nitrogen at reduced pressure and at a temperature between $40-50^{\circ} \mathrm{C}$. The residual oil was pale yellow. No radioactivity due to inorganic iodine could be extracted from the oil with sodium sulfite solution after standing in the dark for ten days. The yield was $56 \mathrm{gms}$. In several runs $80-90 \%$ of the iodine used was incorporated in the fat, as determined both by radioactivity measurements and iodine titration.

A $10 \%$ emulsion of radioactive oil in water was made with the aid of "Demal 14" as follows: One part of Demal was dissolved in two parts of oil, water was added and the entire mixture was blended for 10 minutes in a Waring blender and then recirculated in a high pressure homogenizer for 60 minutes. Microscopic examination revealed the larger fat droplets to be approximately 0.5 . 2.0 micra in diameter. 4

\section{Radioactivity determination $(18,19)$}

Either 2 cc. of blood or 1 cc. of plasma was evaporated for 48 hours at $37^{\circ} \mathrm{C}$. to dryness in an aluminum cup, $2 \mathrm{~cm}$. in diameter. In experiments in which tissues were analyzed, several one-gram specimens of liver, spleen, lung, mesenteric fat, omentum, kidney, intestines, and thyroid were removed in thin slices, immediately after death by exsanguination, wiped dry of all excess blood, and rapidly weighed on a torsion balance. They were then spread out in a thin layer in aluminum cups and evaporated for 48 hours at $37^{\circ} \mathrm{C}$. to dryness.

A two to four hundredfold dilution of the radioactive oil or emulsion which was used for injection was prepared with non-radioactive oil or emulsion. An aliquot of this solution was evaporated with $2 \mathrm{cc}$. of blood or 1 cc. of plasma from a normal dog in order to prepare a standard approximating the dry weight of the experimental samples.

Radioactivity measurements were made on a Tracerlab Autoscaler with a Victoreen Geiger tube (bell type with end mica window weighing $\left.3.6 \mathrm{gms} . / \mathrm{cm}^{2}\right)$. The tube and samples were shielded with 1.5 inches of lead. All specimens were at least five times background, unless otherwise indicated.

Radioactivity measurements were calculated for total activity circulating in the blood or plasma in per cent of total activity injected in the form of oil or emulsion. Tissue radioactivity was calculated in terms of radioactivity per whole weighed organ or tissue in per cent of total activity injected. The standards prepared with normal dog blood were used in making these calculations. For the purpose of these calculations the skeletal muscle was assumed to have $30 \%(20)$ and the blood volume $10 \%$ of the body weight. The hematocrit was taken as $50 \%$.

4 Acknowledgment is due the Esselen Research Corporation, Boston, for assistance in the preparation of several of the early emulsions.

\section{ANIMAL EXPERIMENTS}

Subcutaneous injection of radioactive iodized oil

Ten cc. of radioactive oil were injected into the subcutaneous tissues of the flank in each of two dogs. Just prior to the injection of the oil, one of these dogs was also given $20 \mathrm{mgs}$. of hyaluronidase ${ }^{5}$ in $25 \mathrm{cc}$. of saline into the same site. In both dogs the injected tissues were massaged to disperse the injected material.

The rate of absorption of radioactive fat into the circulation was determined by measuring serial blood samples for radioactivity. At no time in the following 48 hours was more than $0.25 \%$ of the total radioactivity injected found in the circulating blood (Table I). After four to five days the sites of injection retained virtually all of the oil still unabsorbed.

TABLE I

Radioactivity* circulating in the blood $\dagger$ of dogs after the subcutaneous injection of $10 \mathrm{cc}$. radioactive iodized soya bean oil

\begin{tabular}{l|c|c|c|c|c|c|c|c|c|c}
\hline \hline $\begin{array}{c}\text { Dog } \\
\text { no. }\end{array}$ & $\begin{array}{c}\text { Dose of } \\
\text { hyaluro- } \\
\text { nidase }\end{array}$ & \multicolumn{7}{|c}{ Hours after injection } \\
\cline { 2 - 7 } & 1 & 4 & 6 & 8 & 10 & 24 & 28 & 48 & 72 \\
\hline 1 & $\begin{array}{c}m g s . \\
0\end{array}$ & - & - & - & 0.14 & 0.16 & 0.18 & 0.2 & 0.14 & - \\
\hline 2 & 20 & .08 & 0.14 & 0.10 & 0.10 & 0.25 & 0.22 & & - & 0.30 \\
\hline
\end{tabular}

* Radioactivity expressed in per cent of total radioactivity injected.

$\dagger$ Blood volume estimated as $10 \%$ of body weight.

Ten cc. per kilogram of body weight of the radioactive fat emulsion were injected subcutaneously into each of four dogs. In three of these dogs 5-10 mgs. of hyaluronidase were injected into the same site just before injection of the emulsion. The tissues were massaged following injection of the emulsion. The results were similar to those with liquid radioactive oil. At no time during the following week was more than $0.5 \%$ of the total radioactivity injected found in the circulating blood (Table II). Analysis for radioactivity of the major tissues three to five days after injection

5 Hyaluronidase is said to increase the rate of absorption of substances injected subcutaneously (21-24) by virtue of the increased surface area made available by its hydrolytic action on the hyaluronic acid gel of the connective tissues. Hyaluronidase was provided through the courtesy of Schering Corp. The assay of each milligram was 50 turbidity reducing units. 
TABLE II

Radioactivity* circulating in the blood $\dagger$ of dogs after the subcutaneous injection of radioactive oil emulsion

\begin{tabular}{|c|c|c|c|c|c|c|c|c|c|c|c|c|c|c|c|c|c|c|}
\hline \multirow{2}{*}{$\begin{array}{l}\text { Dog } \\
\text { no. }\end{array}$} & \multirow{2}{*}{$\begin{array}{c}\text { Dose of } \\
\text { hyaluro- } \\
\text { nidase }\end{array}$} & \multicolumn{17}{|c|}{ Hours after injection } \\
\hline & & 1 & 3 & $4-5$ & 8 & 12 & $16-18$ & $23-24$ & 28 & $33-36$ & 48 & 54 & $72-75$ & 90 & 120 & 140 & 160 & 180 \\
\hline $\begin{array}{l}3 \\
4 \\
6 \\
7\end{array}$ & $\begin{array}{r}\text { mgs. } \\
10 \\
5 \\
10 \\
0\end{array}$ & $\begin{array}{c}0 \\
0.02\end{array}$ & $\begin{array}{l}0.07 \\
0.01 \\
0.04 \\
0.02\end{array}$ & $\begin{array}{l}0.04 \\
0.03\end{array}$ & $\begin{array}{l}0.10 \\
0.06\end{array}$ & $\begin{array}{l}0.22 \\
0.11 \\
0.08 \\
0.05\end{array}$ & $\begin{array}{l}0.04 \\
0.03\end{array}$ & $\begin{array}{l}0.23 \\
0.45 \\
0.07 \\
0.06\end{array}$ & $\begin{array}{l}0.12 \\
0.07\end{array}$ & $\begin{array}{l}0.48 \\
0.10 \\
0.06\end{array}$ & $\begin{array}{l}0.39 \\
0.14 \\
0.14\end{array}$ & $\begin{array}{l}0.24 \\
0.11 \\
0.16\end{array}$ & $\begin{array}{l}0.12 \\
0.12 \\
0.25\end{array}$ & $\begin{array}{l}0.07 \\
0.33\end{array}$ & $\begin{array}{l}0.13 \\
0.28\end{array}$ & 0.20 & 0.25 & 0.23 \\
\hline
\end{tabular}

* Radioactivity expressed in per cent of total radioactivity injected.

† Blood volume estimated to be $10 \%$ of body weight.

revealed that less than $0.5 \%$ of the total radioactivity injected was present in all the tissues combined. The thyroid gland also contained the same low order of radioactivity as other tissues. Only a trace of radioactivity was found in the feces and urine. The injection site contained nearly all of the emulsion. Therefore, neither emulsification nor hyaluronidase improved the absorption of radioactive fat from the subcutaneous tissues.

\section{Intraperitoneal injection of radioactive iodized oil}

Ten cc. per kilogram body weight of radioactive fat emulsion were injected intraperitoneally into six dogs. In five of these dogs (Nos. 9, 11-14), 5-10 mgs. of hyaluronidase in $50 \mathrm{cc}$. of saline were injected intraperitoneally five to 10 minutes prior to the administration of the oil. The results are summarized in Table III.

In Dog 10, which did not receive hyaluronidase, less than $0.5 \%$ of the total radioactivity injected was found in the circulating plasma. The same was true in Dogs 11,12, and 14, which did receive hyaluronidase. Dog 11 was first given the fat emulsion without hyaluronidase; but six weeks later, he received it again with hyaluronidase. The circulating radioactivity was not increased by the hyaluronidase.

In Dogs 9 and 12, by the 12th day after injection, $8 \%$ and $3 \%$ respectively of the total radioactivity injected was found in the circulating plasma.

The tissues of Dogs 10,12, 13 and 14, sacrificed 12-15 days after injection, failed to reveal any radioactivity, except in the peritoneal cavity, which was free of any noticeable reaction to the presence of the fat or hyaluronidase.

\section{DISCUSSION}

Our finding of a low order of radioactivity in plasma and tissues, including the thyroid, confirm the view that the subcutaneous route is unsatisfactory for the parenteral administration of fat or fat emulsion. The absorption is too slow and is not noticeably accelerated by hyaluronidase, which does speed up the absorption of water, electrolytes, and plasma $(24,25)$.

TABLE III

Radioactivity* circulating in the plasma $\dagger$ of dogs after the intraperitoneal injection of radioactive oil emulsion

\begin{tabular}{|c|c|c|c|c|c|c|c|c|c|c|c|c|c|c|c|c|c|c|c|c|c|c|}
\hline \multirow{2}{*}{$\begin{array}{c}\text { Dog } \\
\text { no. }\end{array}$} & \multirow{2}{*}{$\begin{array}{l}\text { Dose of } \\
\text { hyaluro- } \\
\text { nidase }\end{array}$} & \multicolumn{20}{|c|}{ Days after injection } & \multirow{2}{*}{$\begin{array}{l}\text { Wt. loss } \\
\text { or gain } \\
\text { by the } \\
14 \text { th day }\end{array}$} \\
\hline & & 0.17 & 0.5 & 1 & 2 & 2.6 & 3 & 4 & 5 & 6 & 7 & 7.5 & 8 & 9 & 12 & 13 & 14 & 16 & 17 & 21 & 26 & \\
\hline $\begin{array}{r}9 \\
10 \\
11 \\
11 \\
12 \\
13 \\
14\end{array}$ & $\begin{array}{c}\text { mgs. } \\
5 \\
0 \\
0 \\
5 \\
5 \\
10 \\
5\end{array}$ & $\begin{array}{l}0.27 \\
0.06 \\
0.09\end{array}$ & \begin{tabular}{|l|}
0.24 \\
0.07 \\
0.08
\end{tabular} & \begin{tabular}{|l|}
0.24 \\
0.08 \\
0.14 \\
0.08 \\
0.19 \\
0.08 \\
0.04
\end{tabular} & $\begin{array}{l}1.5 \\
0.14 \\
0.27 \\
0.11 \\
0.40 \\
0.05\end{array}$ & $\begin{array}{c}0.33 \\
0.33\end{array}$ & \begin{tabular}{|l|}
2.9 \\
0.16 \\
0.46 \\
0.17 \\
0.75 \\
0.05
\end{tabular} & $\begin{array}{l}3.2 \\
0.16 \\
0.72 \\
0.14 \\
0.52 \\
0.43 \\
0.06\end{array}$ & \begin{tabular}{l|} 
\\
0.76 \\
0.17 \\
0.43 \\
0.31 \\
0.07
\end{tabular} & $\begin{array}{l}5.5 \\
0.16 \\
0.36 \\
0.13 \\
0.24 \\
0.11\end{array}$ & $\begin{array}{l}4.5 \\
0.26 \\
0.44\end{array}$ & \begin{tabular}{|l|}
0.13 \\
1.35 \\
0.12
\end{tabular} & $\begin{array}{l}5.2 \\
0.21 \\
0.2 \\
0.19\end{array}$ & $\begin{array}{l}7.2 \\
0.22 \\
\\
0.17\end{array}$ & $\mid \begin{array}{l}8.1 \\
0.06 \\
\\
3.26 \\
0.11 \\
0.12\end{array}$ & $\begin{array}{l}7.7 \\
0.04 \\
1.38 \\
2.7\end{array}$ & $\begin{array}{l}7.4 \\
0.1 \\
0.09\end{array}$ & 1.6 & $\begin{array}{l}6.3 \\
1.02\end{array}$ & $\begin{array}{l}7.2 \\
0.46\end{array}$ & $\left|\begin{array}{l}0.2 \\
0.21\end{array}\right|$ & $\begin{array}{c}\text { lbs. } \\
-8 \\
+0.5 \\
-3.5 \\
+2 \\
-7 \\
0 \\
+2\end{array}$ \\
\hline
\end{tabular}

* Radioactivity is expressed in per cent of total radioactivity injected.

† Plasma volume estimated to be $5 \%$ of the body weight. 
Absorption of fat from the peritoneal cavity is also unsatisfactory. In two of the five dogs which received hyaluronidase, a relatively high level of circulating radioactivity was present from the third day up to the 21st (Dog 9), and the 16th (Dog 12) day respectively following injection of the emulsion. Since injected ionic iodine is rapidly excreted (18), the continuous presence of radioactive iodine in the plasma of these dogs is due either to the continuous slow absorption of the iodized fat or to slow liberation of $\mathrm{I}^{131}$ from the iodized fat in situ. How much of the circulating radioactivity was ionic iodine cannot be stated. In another publication (16), data are presented showing that 24 hours after intravenous injection of emulsified radioactive fat, only $10 \%$ of the radioactivity in plasma is in the form of ionic iodine, while $60 \%$ is in the lipid fraction. We did not make this fractional determination in Dogs 9 and 12 , but one might postulate a similar distribution in these dogs. A possible relationship between the nutritional state of the animal and the rate of absorption from the peritoneal cavity is suggested, since there was a weight loss of 7-8 lbs. in the course of the experiment in Dogs 9 and 12, whereas Dogs 10, 13, and 14 either maintained or gained weight. Dog 11 showed greater absorption in the second experiment, in which there was a weight loss of $3.5 \mathrm{lbs}$., than in the first experiment in which there was a weight gain of $2 \mathrm{lbs}$.

Although virtually all the fat injected intraperitoneally remained there at least $16-17$ days, intraperitoneal adhesions did not form in dogs which received hyaluronidase. Since adhesions have been observed from intraperitoneally injected fat without hyaluronidase (5), these observations suggest that this enzyme may be useful to prevent adhesions.

\section{CONCLUSIONS}

A method for preparing radioactive iodized oil is described.

Following subcutaneous or intraperitoneal injection of emulsions of this oil, absorption was slow and nearly all of it remained at the site of injection.

Hyaluronidase did not increase the rate of absorption of tagged fat from the subcutaneous or peritoneal space.

\section{BIBLIOGRAPHY}

1. Mills, L. H., and Murlin, J. R., The influence of oils and of lecithin on the protein metabolism. Proc. Soc. Exper. Biol. \& Med., 1910, 7, 166.

2. Mills, L. H., and Congdon, E. A., The utilization of fats and oils given subcutaneously. Arch. Int. Med., 1911, 7, 694.

3. Schwartze, E. W., Behavior of a fixed oil (peanut oil) injected intraperitoneally. J. Pharm. \& Exper. Therap., 1921, 17, 115.

4. Koehne, M., and Mendel, L. B., The utilization of fatty oils given parenterally. J. Nutrition, 1929, 1, 399.

5. Narat, J. K., Observations on parenteral administration of fat emulsions. Am. J. Digest. Dis. \& Nutrition, 1937, 4, 107.

6. Narat, J. K., Parenteral use of fat emulsions in urosepsis. Urol. \& Cutan. Rev., 1938, 42, 17.

7. Lerner, S. R., Chaikoff, I. L., Entenman, C., and Dauben, W. G., Oxidation of parenterally administered $\mathrm{C}^{14}$-labelled tripalmitin emulsions. Science, 1949, 109, 13.

8. Schoenheimer, R., and Rittenberg, D., Deuterium as an indicator in the study of intermediary metabolism. J. Biol. Chem., 1935, 111, 175.

9. von Bodo, R., and Schaeffer, L., Fortgesetzte Untersuchungen über das Schicksal intravenös infundierter Fettemulsionen. Arch. f. exper. Path. u. Pharmakol., 1927, 124, 326.

10. Murata, M., Parenteral resorption of colloids. Biochem. Ztschr., 1932, 245, 67.

11. Artom, C., Sur le rôle des phosphoaminolipides dans le métabolisme des graisses; expériences avec introduction parentérale de graisses iodées. Arch. internat. de physiol., 1933, 36, 101.

12. Artom, C., and Peretti, G., Sur le rôle des phosphoaminolipides dans le métabolisme des graisses; expériences avec introduction orale de graisses iodées. Ibid., 1933, 36, 351.

13. Artom, C., and Peretti, G., Sur le rôle des phosphoaminolipides dans le métabolisme des graisses; les lipides de la muqueuse intestinale pendant l'absorption de graisses iodées. Ibid., 1935, 42, 61.

14. Sato, G., Uber die Jodabspaltung aus jodiertem Fett im Tierkörper und ihre Beziehung zum intermediären Fettstoff wechsel. Tohoku J. Exper. Med., 1936, 28, 503.

15. Pellegrini, H., Absorption and distribution of iodized fat following extirpation of adrenals. Atti. d. $r$. Accad. d. Fisiocrit. in Siena, 1947, 13, 290.

16. Rutenburg, A. M., Seligman, A. M., and Fine, J., Studies with radioactive iodized fat. II. The tissue distribution of emulsified fat following intravenous administration. J. Clin. Invest., 1949, 28, 1110.

17. Greenbaum, F. R., New method for iodation and chlorination of vegetable and animal oils. Am. J. Pharm., 1937, 109, 407. 
18. Seligman, A. M., Rutenburg, A. M., and Friedman, O. M., Distribution studies in mice following the intravenous injection of diethyl $\beta$-iodoethyl amine hydrochloride prepared with radioactive iodine. J. Nat. Cancer Inst., 1949, 9, 261.

19. Seligman, A. M., Shear, M. J., Leiter, J., and Sweet, B., Chemical alteration of polysaccharide from Serratia marcescens. I. Tumor necrotizing polysaccharide tagged with radioactive iodine. J. Nat. Cancer Inst., 1948, 9, 13.

20. Gibson, J. G., II, Seligman, A. M., Peacock, W. C., Aub, J. C., Fine, J., and Evans, R. D., The distribution of red cells and plasma in large and minute vessels of the normal dog, determined by radioactive isotopes of iron and iodine. J. Clin. Invest., 1946, 25, 848.
21. Hoffman, D. C., and Duran-Reynals, F., The influence of testicle extract on the intradermal spread of injected fluids and particles. J. Exper. Med., 1931, 53, 387.

22. Sannella, L. S., The effect of testicular extract on the distribution and absorption of subcutaneous saline solutions. Yale J. Biol. \&.Med., 1940, 12, 433.

23. Duran-Reynals, F., Tissue permeability and spreading factors in infection. Bact. Rev., 1942, 6, 197.

24. Hechter, O., Dopkeen, S. K., and Yudell, M. H., The clinical use of hyaluronidase in hypodermoclysis. J. Pediat., 1947, 30, 645.

25. Banks, H. H., Seligman, A. M., and Fine, J., The effect of hyaluronidase on absorption of parenterally administered dog plasma protein. J. Clin. Invest., 1949, 28, 548. 